\title{
Principles and Norms of the Administrative Law in the Making Government Instruments
}

\author{
E Agustina ${ }^{1}$ \\ \{ennyagustinadua@yahoo.com ${ }^{1}$ \} \\ Kader Bangsa University, Faculty of Law, Palembang, South Sumatra, Indonesia ${ }^{1}$

\begin{abstract}
The idea of a legal state was first put forward by Plato, when he wrote Nomoi, as a third written work made in his old age. While in the first two written, Polytheia and Politicos, no legal state has yet to appear. Plato points out in Nomoi that good implementation state was on good arrangements law. Plato's ideas of a state of the law were increased assertive when it was supported by his student, Aristotle, a good state is a state governed by a constitution and rule of law [1]. The approach was used a statute approach and concept approach. The result of the research show that The regulations of laws had characteristics: It was general and comprehensive, thus the opposite of special and limited traits.and it was universal. It was created to face upcoming events that were not yet clear on their concrete form. Therefore, it was not formulated to overcome certain events only.
\end{abstract}

Keywords: Norms, Principles Administrative Law, Government Instruments

\section{Introduction}

The idea of a legal state was first put forward by Plato, when he wrote Nomoi, as a third written work made in his old age. While in the first two written, Polytheia and Politicos, no legal state has yet to appear. Plato points out in Nomoi that good implementation state was on good arrangements law. Plato's ideas of a state of the law were increased assertive when it was supported by his student, Aristotle, a good state is a state governed by a constitution and rule of law [1].

The ideas of a legal state were still vague and sink for a very long time, then reappeared more explicitly in the nineteenth century, with the emergence of the rechtsstaat concept of Freidrich Julius Stahl, inspired by Immanuel Kant's thought. According to Stahl, elements of legal state rechtsstaat were as follows [1]:

a. Protection of human rights

b. Separation or shared power to guarantee those rights

c. Governing under the legislation, and

d. The administrative court in dispute.

In the Anglosaxon region, the concept of the rule of law state of A.V. Dicey followed the elements [1]:

a. The supremacy of the rule of law supremacy of the law; absence of absolute power absence of the law;

b. The same position in the face of law equality before the law. This argument applied, both to ordinary people and officials; and 
c. Guarantees of human rights by law and court decisions.

In the development, the conception of the law state then undergoes a general improvement seen from the following elements [1]:

a. The system of government state based on people's sovereignty.

b. That the government to performing the duties and obligations was on the laws or regulations.

c. A guarantee of human rights citizens.

d. Shared of power within the state.

e. The supervision of judicial bodies rechterlijke controle which is free and independent, in the sense that the judicial institution was completely impartial and not under the influence of the executive.

f. The existence of a real role of community members or citizens to participate in overseen the actions and implementation of policies undertaken by the government.

g. The existence of an economic system that guarantee an equitable distribution of resources necessary for the prosperity of citizens.

Based on the provisions of Article 1 Section 3 of the Constitution 1945 of the Republic Indonesia, "Indonesia is a constitutional state" which embraces decentralization in the implementation of government, as implied in Article 18 Section 1 Constitution of the Republic Indonesia of 1945 "The Unitary State of the Republic Indonesia was divided into provincial, districts and municipalities had regional governments, which were regulated by law ". As a state of law, every administration of government affairs was on applicable law wetmatigheid van bestuur. As a state of law, every execution of governmental affairs was on applicable law wetmatigheid van bestuur. As a country that embraces decentralization means that government affairs consist of central government affairs and regional government affairs. This means that there is a central government device and there is a regional government device that was given autonomy of freedom and independence to manage the affairs of the regional household [1].

Referred to the formulation of state objectives listed in the fourth Alenia of the Preamble to the Constitution 1945, especially on the editorial of "promote the general welfare", some argue that Indonesia adheres to the welfare state, such as Azhary and Hamid S. Attamimi. According to Hamid S. Attamimi, said that the state of Indonesia was established since its intention to establish itself as a state on the law, as rechtsstaat. Even the rechtsstaat Indonesia was the rechtsstaat that promoted the general welfare, educate the life of the nation, and realize social justice for all the people of Indonesia [1].

According to Philipus M. Hadjon, the idea of rechtsstaat tends toward legal positivism which carried the consequence that the law was consciously established by the legislature. As a rule of law, the law was placed as the rule of the game in the exercise of statehood, government, and society, while the objectives of the law itself included "... opgelegd om de samenleving vreedzaam, rechtvaardig, en doelmatig te ordenen" laid down to organize a peaceful society, fair, and meaningful [1].

The execution of the duties of government and state in a law state has the rules of the law written in the constitution or the rules collected in the constitutional law. However, for the implementation of technical issues, this constitutional law was not fully implemented effectively. That is, constitutional law required other laws of a technical nature. The law was the Law of State Administration. Since the state was a power organization machtenorganisatie, ultimately the law of state administration emerged as an instrument to oversee was used of governmental power.

Therefore, the existence of State Administrative Law arises because of the implementation of state power and government in a state law, which demands and required the implementation 
of state duties, government, and society on the law. According to Philipus M. Hadjon said, the size or indication of the rule of law was the functioning of administrative law, otherwise a state was not a legal state in reality when the administrative law did not work [1].

Based on the background that has described and more focused in discussed, so described the discussion properly, and then arranged several problems. The main issues were as follows: 1). What were the meaning of legislation, policies, and decisions on the administrative law? And 2).What were the principles and norms of the administrative law in the draft of the legislation, policy regulations, and decisions?.

\section{Method}

This Research was used library research normative legal research.[2] The normative juridical method intended to explain various Principles and Norms of the Administrative Law in the Making Government Instruments.

\section{Result and Discussion}

\subsection{Definitions of Legislation-Invitations, Policies, and Decisions under the Administrative Law}

\section{a. Legislation}

The rule is a law in the abstract to or general norms that were bound generally applicable and the duty is regulated things that were general [3].

According to the Elucidation of Article 1 number 2 of Law number. 5 of 1986 on State Administrative Courts, the laws and regulations were all general bind rules issued by the People's Legislative Assembly with the government, both at the central and regional levels which were also bound in general. The formulation of such laws and regulations included material and formal insights [3].

Based on the formulation of the explanation of Article 1 point 2, Law number. 5 of 1986, it was concluded that the decision of the body or state administrative officials which were general arrangements besluit van algemene strekking included legislation algemeen verbindende voorschriften [4].

According to a German scholar, Paul Laband, the law was formal and hylic defined wet in formele zin and wet in materialele zin. The law in the formal sense wet in formele zin was any rule government decree associated with the way of the occurrence or mode of formation. While in Indonesia, the meaning of the Law in a formal sense was every legal product made by the President together with the House of Representatives. While the law in the hylic sense was a strict rule of law so that the rule of law has a bound nature.

According to Paul Laband bind nature of a rule of law was required two elements, the firm determination anordnung, and the rule or the content of the law itself rechtsstaat. According to Buys in his book De Grond wet, Toelichting en Kritiek 1883, argued that the meaning of the law in the hylic sense was any government decision overhead whose contents bind directly to every resident [3]. Regard to legislation, A. Hamid S. Attamimi was written as follows [5]: "The term legislation wettelijkeregels was literally interpreted as regulated the law, both in the form of both own and lower laws which constitute attribution or delegation of legislation. On the basis of attribution and delegation of legislative authority then those classified as legislation in our country were laws and regulations were lower than such as government regulations, a presidential decree contained a regulation, a ministerial decree contained a 
regulation, a decision of the head of a non-departmental government agency contained the regulation, the decision of the director-general of the department in the form of a law contained the rules, the regional regulation 1, the decision of the regional governor provisions of regional regulation 1, regional level II, and the decision of regents / mayors of regional heads shall contain regulations implemented the provisions of regional regulation II. "

Legislation has the following characteristics [1]:

1) General and comprehensive, thus the opposite of specific and limited traits.

2) It was universal. It was created to face upcome events that were not yet clear on their concrete form. Therefore, it is not formulated to overcome certain events only.

3) It has the power to correct and improved itself. It was not unusual for a regulation included a clause that contains the possibility of a review.

According to Article 1 number 2 of Lumber no. 10 the Year 2004 Concerned the Establishment of Laws and Regulations, the meaning of legislation was a written regulation established by a state institution or authorized and publicly bound the authority. General bound legislation algemeen verbindend voorschrift was also referred to as the law in the hylic sense wet in materialele zin, ieder rechtsvoorschrift van de overheid met algemeen strekking all written laws of public binding government.

Based on the above legal norm qualifications, the legislation was general-abstract. The words were general-abstract characterized by the following elements [1]:

1) Tijd een regel geldt niet slechts op een moment; Time not only valid at a given time;

2) Plaats een regel geldt niet slecht op een plaats; Place not only applied to certain places;

3) Persoon een regel geldt niet slechts voor bepaalde persoon; People not only applied to certain people; and

4) Rechtsfeit een regel geldt niet voor een enkel rechtsfeit, maar voor rechtsfeitendie herhaalbaar zijn, dat wil zeggen zich telkens voor kunnen doen. Legal facts not just for certain laws, but for various legal facts that were repeated, in other words for repeated acts.

\section{b. Policy}

Wisdom or Freies Ermessen in German came from the word frei which means free, independent, unbound. The word freis means free man, while ermessen means to consider, judge, guess, judgment, judgment or decision. English called it discretion which means wisdom, discretion, caution, or discretionnaire adjective, which means submitted to wisdom with freedom decided or chose [3].

Stanley De Smith and Rodney Brazier, defined Ermanessen's discretion / freies as "... power to choose between alternative courses of action ...", while H.W.R. Wade, mentions a key principle of Ermessen's discretion / freies was "... the rule that the participation of nonmembers in the deliberation or decision of a collective body may invalidate its acts ...". Meanwhile, Amrah Muslimin, defined ermessen fries as "... the field moved as wisdom or freedom of wisdom ..." [6].

In contrast to Hans J. Wolf in his Verwaltungsrecht I, as quoted by Marcus Luqman states the Ermessen freies was not over-interpreted, as if the bodies or administrators of the state may act arbitrarily or without basis or on an unclear basis or with subjective-individual considerations. Therefore, according to Hans J. Wolf said, they act on wisdom [7].

The Ermessen freies were seen from the framework of the administrative regime system in Germany, then the Ermessen freies were means of provided the space for state administration took actions that were not fully bound by law. While in the British state administration system, according to A.V. Dicey, as quoted by Bagir Manan, "... discretionary power contains the 
freedom of the crown or the apparatus for approval or arrangement by parliament. So discretionary came from the prerogative and not on the law ... "[3].

Sjachrab Wet, was given the definition of freie Ermessen as discretion in determining the policies through the attitude of the administration of the state that accountable. Thus, the freie Ermessen was the freedom to act on own initiative solved sudden and urgent problems arose suddenly, where the law did not regulate them and accounted for both legally and morally [3].

\section{c. Decision}

The decision is one of the important study objects in administrative law, mainly because the decision is the object of dispute that became the absolute competence of administrative court according to Law number 5 the Year 1986. Unless the decision is one of the juridical instruments of government which is widely used by the government in did actions to express stated desire [3].

The term decision is a translation of the term beschikking derived from Dutch, while in French was called the administrative acted term, and in German was called verwaltungsakt [3]. The term beschikking in Indonesia was first introduced by WF. Prins. Which is means provision [1]. Djenal Hoesen said that use of terminology would probably more appropriate to avoid confusion in terms of provision. According to him, in Indonesia, the term provision already has a juridical technical sense, as a decree of the People's Consultative Assembly that applied to the outside and inside [8].

Some scholars who provided the definition of beschikking, among others [3]

1) Mr. Drs. E. Utrecht in his book Introduction to Indonesian Administrative Law stated that beschikking is a one-sided act of public law carried out by means of government on the basis of special power.

2) Mr. WF. Prins in his book Inleiding in het Administratiefrecht van Indonesia mentions beschikking as a unilateral legal action in the field of government carried out by means of government on the existing authority on the tool or organ.

3) Van der Pot in his book Nederlandsch Bestuursrecht stated beschikking is a legal act by the means of government, the statements of the desire of the instruments of government in the implement of privilege, the intention of making changes in the field of nexus-nexus of law. Based on several definitions of these scholars, there appear some elements found in beschikking [1]

1) Statement of unilateral desire enjizdige schriftelijke wilsverklaring;

2) Issued by government organs bestuursorgaan;

3) Based on public legal authority publiekbevoegdheid;

4) Aimed at special things or concrete and individual events;

5) A view to cause legal consequences in the administrative field

From the various definitions, beschikking decision is a public legal act of one-sided, was done by means of government in a narrow sense on a special power or authority with the intention of changed the legal relationships [3]. 


\subsection{Principles and Norms of the Administrative Law in the Establishment of Legislation, Policy Regulations Beleidsregel, and Decision Making.}

\section{c. Principles and Legal Norms of State Administration in the Establishment of Legislation}

In the theory of welfare state welfare state, verzorgingsstaat, the task of government was not only limited to implement legislation made by the legislature. According to the perspective of the welfare state, the government was obliged to carry out the public interest bestuurszorg or pursues social welfare, which in the exercise of such obligations the government was authorized to intervene in the life of society, within the limits permitted by law. Along with such intervention, the government was also authorized to create and use legislation. Another meaning, the government has the authority in the field of legislation.[1] The concept of separation of powers, especially with regard to the executive function which is only as the implementation of the law without the authority made laws and regulations, along with the development of state and governmental tasks, not only lose the relevance but also in the practice of encountered many obstacles. Therefore, although there is a claim that the legislative organs were the main organs of legislation, while the executive organ as a secondary organ in the draft of legislation, but as mentioned H.W.R. Wade, only measure in terms of numbers, most legislation was shaped by the executive government rather than by the legislature. Although most of the legislation was constituted by executive organs, it did not mean that the existence of legislative bodies within a state of the law became unnecessary. Therefore, it said, "... Perhaps was more realistic said that the government made the laws subject to prior parliamentary consent". That is because the legislative authority for the government or executive organ was basically derived from the law in accordance with the principle of legality in the state law which means came from parliamentary approval [1].

1) The idea of power-shared that emphasizes more on function than organ separation was found in the doctrine of separation of powers. Thus, the function of the formation of legislation was separated from the function of implemented the government. The function of the formation of legislation was also attached to the administration of the state, either as an independent power or as a power which is run jointly with the legislature.

2) Understand that given power to the state or government to interfere with the livelihood of society, whether as state power or welfare state. According to the state of power, the intervention of the state or government was done in order to limit and control the people. One of the things that formally supports the exercise of such powers was the creation of various legal instruments that provided the basis for the state or government to act.

3) To support rapid and complex society changed, it was necessary to accelerate the formation of law. This encourages state administration played a larger role in the formulation of legislation. As a welfare state, various legal instruments were needed that was not simply handed over by the legislature. To conduct general welfare, state administration required the authority in order to regulate without disregard the principles of the state on the law and the general principles of good government. In such circumstances, the grown power of state administration in the field of legislative formation.

4) The development of various types of laws and regulations ranging from the Constitution to regional legislation. The legislature did not form any kind of legislation but was limited to the law and the Constitution. Other types were made by the state administration.

In addition, there were other reasons given the authority of legislation for the government that was related to the nature of the norms of constitutional law and state administrative law, 
the general-abstract Algemeen-abstract. When confronting concrete events, the norms of a general-abstract nature require a concrete-individual juridical instrument [1]. Therefore, in the literature of state administrative law there was the term step back legislator terugtred van de wetgever. This retreat was taken in an attempt applied the abstract-general and abstract norm of public administration law to concrete and individual events.[1], In this case A.D. Belinfante said that:

"De wet geeft daan aan een bestuurlijk orgaan de bevougdheid door administratiefrechtelijke rechtshandelingen rechtsbetrekkingen tusssen dat orgaan en burgers te scheppen. De terugtred is onvermijdelijk. Zij biedt het voordeel van neel verder gaande differentiatie naar bijzonderheden van de concrete toestand and de wetgever ooit zou kunnen bereiken. "

The law authorizes government organs to create administrative-legal rules in the context of legal relations with citizens. This step back was not avoided and provided greater benefits for the indefinite period afforded by legislators.

\section{d. Principles and Norms of the Administration Laws in Making Policy Regulations Beleidsregel}

Wisdom or freies Ermessen was defined or formulated as [3]:

"Freedom or discretion acts on the law's own initiative wisdom permitted, to resolve urgent immediate emergency matters, whose arrangements did not yet exist or vague or vague authority, was accounted for either law and morals."

The definition of wisdom mentioned above according to SF Marbun consists of three elements [3]:

1) The existence of freedom permitted by law to the state administration to act on own initiative.

2) There were important and urgent issues was resolved immediately

3) The responsible morally and legally as the draft and application of legislation, that was pay attention to some requirements, made and application of policy rules also pay attention to some requirements.

According to Indroharto cited by Ridwan, policy-made pay attention to the follow matters [1]:

1) It was not contrary to the ground rules containing the discretionary authority described;

2) It was not clearly contrary to sound reason;

3) It was carefully prepared, all interests, exist circumstances and alternatives need was considered;

4) The content of the policy provided sufficient clarity on the rights and obligations of the affected citizens;

5) The objectives and fundamentals of the policy considerations were taken clear;

6) It fulfills the requirement of material legal certainty, that the rights that had obtained from the affected citizens were respected, then also the expectations of the appropriate citizens had caused and not denied.

e. Principles and Norms of the Administrative Law In Making Decision of Understanding, the decision according to Article 1 point 3 of Law Number.5 Year 1986 jo Article 1

Numeral 9 of Law number.5 year 2009 on the Second Amendment to Law Number.5 of 1986 concerned Administration of the Administrative Law [3]: 
"A written determination, issued by the Board or Administrative Officer of the State, contained statutory acts of state law, which, by virtue of applicable, concrete, individual, and final legislation, which given rising to legal consequences for a person or a Legal Entity Civil."

In the definition above, drawn juridical elements of the decision according to positive law as followed [9]:

a. A written stipulation;

b. Issued by the state administrative body or officer;

c. Contains legal action of state administration;

d. Based on the prevailing laws and regulations;

e. Concrete, individual and final;

f. Included legal consequences for a person or a civil legal entity.

State administrative decision-making takes into account some of the requirements for such decisions become lawful rechtsgeldig and had legal force rechtskracht and implemented. The requirement was considered in made this decision included hylic requirements and formal terms, [1]:

a. Hylic requirements consist of:

1) The governmental organs that made decisions authorize; Because of the decision of a wilsverklaring, so the decision was not contain juridische gebreken in dewilsvorming defects, such as bedrog, dwang or brioping, dwaling;

2) Decisions were in a particular situation;

3) The decision was made and without violates any other rules, and the content and purpose of such decisions were in accordance with the content and purposes of basic rules.

b. Formal conditions consist of:

1) The conditions prescribed in connection with the preparation of the decision and the manner in which the decision made was fulfilled;

2) Decisions were given the form prescribed in the laws and regulations on which the decree was issued;

3) Conditions related to the execution of such decisions were fulfilled;

4) The period of time was determined between the incidence of the things which cause the creation and the publication of the decision was taken into account.

This hylic requirement and formal requirements had fulfilled, then the decision was lawful rechtsgeldig, it was accepted as a part of a legal order or in accordance with the existing legal provisions both procedurally / formally and hylic [1].

\section{Conclusion}

The rules were laws in the abstract to or general norms that were generally binding generally applicable and the duty was regulated general matters. Based on the explanation of Article 1 Sub-Article 2 of Law Number 5 Year 1986 regarded State Administrative Court, the law and regulation were all general bind regulations issued by the People's Legislative Assembly together with the government both at central and regional levels, as well as all decisions of bodies or state administrative officials, both at the central level, as well as in the regions, which were also publicly bind.

The regulations of laws had characteristics: It was general and comprehensive, thus the opposite of special and limited traits. It was universal. It was created to face up come events that were not yet clear on their concrete form. Therefore, it was not formulated to overcome certain events only.It has the power to correct and improved itself. It was customary for a 
regulation included a clause containing the possibility of a review. The policy regulation serves only as part of the operational performance of governmental duties, because not changed or in violation of legislation.

\section{Suggestions}

From the various problems described, the authors provided advice, in order to maintain legal certainty, and in order to maintain the legal benefits, the government in terms of legislative or decision made on the principles contained in the Administrative Law, so that the discretion appear in the future was avoided.

\section{References}

[1] H. Ridwan, State Administration Law Revised Edition. Jakarta: Raja Grafindo Persada, s2011.

[2] S. Soerjono, Sosiologi: Suatu Pengantar. Jakarta: Raja Grafindo Persada, 1990.

[3] S. F. Marbun and M. Mahfud MD, Principles of State Administration Law. Yogyakarta: Liberty, 2006.

[4] M. P. Hadjon, Introduction to Indonesian Administrative Law Introduction to the Indonesian Administrative Law. Yogyakarta: Gadjah Mada University Press, 1999.

[5] A. H. S. Attamimi, "Difference between Legislation and Policy Regulation," in 46th PTIK Anniversary Speech, 1992.

[6] A. Muslimin, Some Principles and Understanding Principles on Administration and Administrative Law. Bandung: Alumni, 1985.

[7] S. Lukman, Manajemen Kualitas Pelayanan. Jakarta: STIA LAN Press, 2000.

[8] D. H. Koesoemahatmadja, Principles of State Administration Law. Bandung: Alumni, 1979.

[9] S. F. Marbun, "The Study of Jurisprudence of Aaanwijziq Natuurmonumenten, The Appointment of One Region As Staatnatuurmonument Is Not a General Binding Decision," in Upgrading of State Administration Law Indonesia-Netherlands Cooperation, UNPAD, 1987. 